\title{
The Gilgamesh Effect: The Ethical Consequences of Disconnection
}

\author{
Chris Macdonald ${ }^{1 *}$ \\ ${ }^{1}$ Skylab, United Kingdom \\ *Corresponding author: Chris Macdonald: chrismacdonald@dr.com
}

Citation: Macdonald C. (2020)The Gilgamesh Effect: The Ethical Consequences of Disconnection. Open Science Journal 5(2)

Received: $12^{\text {th }}$ January 2020

Accepted: $27^{\text {th }}$ April 2020

Published: $4^{\text {th }}$ June 2020

Copyright: (C) 2020 This is an open access article under the terms of the Creative Commons Attribution License, which permits unrestricted use, distribution, and reproduction in any medium, provided the original author and source are credited.

Funding: The author(s) received no specific funding for this work

Competing Interests: The author has declared that no competing interests exist.

\begin{abstract}
:
A number of recent experiments have revealed that the mere thought of human connection can increase ethical decision-making whereas the thought of human disconnection can decrease ethical decision-making. This paper provides an appropriate name for the phenomenon, reviews the evidence, and highlights its relevance.
\end{abstract}

Keywords: Ethics, Psychology, Economics, Connection, Loneliness, Love, Human connection, Ethical decision-making, Social isolation, Individualism, Money

\section{Introduction}

The Gilgamesh Effect is the psychological phenomenon where thoughts of human connection increase ethical decision-making whereas thoughts of human disconnection decrease ethical decision-making. The phenomenon gets its name from the ancient Mesopotamian story, The Epic of Gilgamesh, in which the evil King Gilgamesh leaves his decadent tower, sheds his royal clothing, and through various forms of reconnection, becomes a better person (Sandars, 1972). The story, surprisingly well preserved on clay tablets (Dalley, 2009), is regarded as the earliest example of great literature (Schmidt, 2019) and as a result, it is one of the first documented accounts expressing the psychological impact of connection and disconnection.

\section{Experiments}

Many old legends and tales set the villain in a location clearly disconnected from others, be it a mighty tower, a dark cave, haunted woodland, the depths of the ocean, or the pits of hell. At least subconsciously, perhaps, it was observed that human disconnection can lead to compromised ethics. 
In modern times, we can see many vivid examples that when there is some form of human disconnect, we are far from the best versions of ourselves, from road rage to youtube comments. But in addition to various physical forms of disconnect, we now have growing evidence that the mere thought of human disconnection can significantly decrease ethical decision-making (Macdonald, 2019; Macdonald, 2020a; Macdonald, 2020b).

One set of experiments showed that participants who read through sentences that contained themes of human disconnection would score lower on a subsequent ethics test than those who read through sentences that contained themes of human connection (Macdonald, 2019). The inclusion of a control group showed that while the thought of human disconnection can significantly decrease ethical decisions, thoughts of human connection increase ethical decisions, and to a greater degree (Macdonald, 2019).

Another set of experiments showed that the Gilgamesh Effect can also be triggered via simple graphical primes (Macdonald, 2020b). Participants who saw images of stickmen connected by lines scored higher on a subsequent ethics test than those who saw images of stickmen disconnected by lines.

The Gilgamesh Effect has also been triggered via a combination of words and images (Macdonald, 2019). In addition to this, a broad range of priming strategies has been explored which was shown to impact the potency of the effect. For example, the potency was shown to increase with indirect priming strategies (such as via the use of metaphors), and increase further still when the primes appear to come from the participants themselves, which was revealed when participants were asked to list ways that humans are connected or disconnected from one another (Macdonald, 2020a). The varied priming techniques explored also assisted in providing convergent evidence, thus there is greater confidence that the triggered responses are the result of a successfully primed theme rather than the result of any idiosyncratic effects of the primes themselves.

Rather appropriately, given the etymology of the Gilgamesh Effect, there appears to be a link with the psychological impact of money. A known phenomenon in psychology is that participants primed with the idea of money will score lower on an ethics test (Gino et al, 2009; Kouchaki et al, 2013; Macdonald, 2019; Vohs, 2015). And interestingly, one experiment showed that when participants were primed with money, they felt a decreased sense of human connection (Macdonald, 2019). Therefore, one of the reasons why money can trigger a decrease in ethical decision-making might be the Gilgamesh Effect.

\section{Relevance}

Authentic connection is vital for our physical and mental health (HoltLunstad et al, 2010; Flegal et al, 2013). Accordingly, when given the choice of physical pain or isolation, social mammals will opt for the former (McMillan, 2016). It has also been noted that children who experience neglect suffer worse mental health consequences than those who also receive physical abuse (Egeland et al, 1981). And a recent study revealed that both actual and perceived social isolation are strongly associated with an increased risk of early mortality (HoltLunstad et al, 2015). In fact, the latest evidence suggests that the increased risk of mortality from a lack of authentic social relationships is greater than that from obesity (Flegal et al, 2013; Holt-Lunstad et al, 2010). 
The Gilgamesh Effect shows us that in addition to decreased personal health, disconnection can also decrease our ethical judgment. Therefore, disconnection is a cruel, double-edged sword. It harms the individual as well as those around them. Thus authentic human connection not only helps to make us healthier people, it also helps to make us good people, ones who make more morally conscious decisions that benefit others.

The Gilgamesh Effect reminds us that we are particularly susceptible to various means of human disconnection, not only physical barriers but even the mere idea of it, which can be triggered in several discrete ways, from precise words to abstract imagery. Therefore the effect also reminds us of our responsibility as nodes within a complicated web of interconnections. The words we use and the images we share help to create the environments and perspectives of those around us (Bargh et al, 1996; Dijksterhuis et al, 1998).

The Gilgamesh Effect is increasingly relevant in modern times with the rise of technologies that evidently have the ability to decrease our sense of authentic human connection: online shopping, internet pornography, video gaming, online gambling, smartphones, and 'social' media. We also appear to be in a time of widespread political polarization and divisive rhetoric (Aquino et al, 2001; Bail et al, 2018; Brugnoli et al, 2019; Carothers, 2019; Cheng et al, 2017; Cook et al, 2018; Pelletier, 2010; Price-Thomas et al, 2018; Törnberg, 2018).

\section{Conclusion}

While it can appear as though humankind is progressing in a positive linear fashion, we are rapidly losing important connections. We are becoming disconnected from how our products are created, and how our food is grown. We are becoming disconnected from many of the consequences of our systems. We are losing our direct connections with our community, our friends, the natural world, and perhaps, ourselves.

As we increasingly become disconnected, atomized individuals, I see it as no coincidence that we are also experiencing high levels of social phobia, loneliness, depression, anxiety, addiction, inequality, division, corruption, pollution, and resource depletion (Alhassan et al, 2018; Bandelow et al, 2015; Beutel et al, 2017; Bystritsky et al, 2013; Cash et al, 2012; Choi et al, 2020; Cook et al, 2013; Cook et al, 2016; Diffenbaugh et al, 2019; Dimant et al, 2017; Hawkley et al, 2010; Howe, 2015; Jefferson, 2001; Kanter et al, 2008; Koneswaran et al, 2008; Kiss, 2009; Mittal et al, 2015; Scarborough et al, 2014; Vieira, 2012; Wang et al, 2017; Zyglidopoulos et al, 2017).

Let the Gilgamesh Effect remind us of a pertinent set of truths, that we are most vulnerable when we are disconnected, that we are incredibly susceptible to various forms of disconnection, and that we are the best versions of ourselves when we work towards that which can authentically connect us. 


\section{References:}

Alhassan AA, Alqadhib EM, Taha NW,Alahmari RA, Salam M, Almutairi AF. 2018. The relationship between addiction to smartphone usage and depression among adults: a cross sectional study. BMC Psychiatry 18:(148)doi.org/10.1186/s12888-018-1745-4

Aquino K, Tripp TM, Bies RJ. 2001. How employees respond to personal offense: The effects of blame, attribution, victim status, and offender status on revenge and reconciliation in the workplace. Journal of Applied Psychology 86:(1) 52-59doi.org/10.1037/0021-9010.86.1.52

Bail CA, Argyle LP, Brown TW, Bumpus JP, Chen H, Fallin Hunzaker MB, Lee J, Mann M, Merhout F, Volfovsky A. 2018. Exposure to opposing views on social media can increase political polarization. Proceedings of the National Academy of Sciences 115:(37) 92169221doi.org/10.1073/pnas.1804840115

Bandelow B, Michaelis S. 2015. Epidemiology of anxiety disorders in the 21st century. Dialogues in clinical neuroscience 17:(3) 327-335ncbi.nlm.nih.gov/pmc/articles/PMC4610617

Bargh JA, Chen M, Burrows L. 1996. Automaticity of social behavior: Direct effects of trait construct and stereotype activation on action. Journal of Personality and Social Psychology 71:(2) 230244dx.doi.org/10.1037/0022-3514.75.4.862

Beutel ME, Klein EM, Brähler E, Reiner I, Jünger C, Michal M, Wiltink J, Wild PS, Münzel T, Lackner KJ, Tibubos AN. 2017. Loneliness in the general population: prevalence, determinants and relations to mental health. BMC Psychiatry 17:(97)doi.org/10.1186/s12888-017-1262-x

Brugnoli E, Cinelli M, Quattrociocchi W, Scala A. 2019. Recursive patterns in online echo chambers. Sci Rep 9: 20118doi.org/10.1038/s41598-019-56191-7

Bystritsky A, Khalsa SS, Cameron ME, Schiffman J. 2013. Current diagnosis and treatment of anxiety disorders. P \& T : a peer-reviewed journal for formulary management 38:(1) 3057ncbi.nlm.nih.gov/pmc/articles/PMC3628173

Carothers T. 2019. Democracies Divided: The Global Challenge of Political Polarization. Washington, DC: Brookings Institution PressAmazon.com//dp/B07N12HN7D

Cash H, Rae CD, Steel AH, Winkler A. 2012. Internet Addiction: A Brief Summary of Research and Practice. Current psychiatry reviews 8:(4) 292-29doi.org/10.2174/157340012803520513

Cheng J, Bernstein M, Danescu-Niculescu-Mizil C, Leskovec J. 2017. Anyone Can Become a Troll: Causes of Trolling Behavior in Online Discussions. CSCW : proceedings of the Conference on Computer-Supported Cooperative Work. Conference on Computer-Supported Cooperative Work 1217-1230doi.org/10.1145/2998181.2998213

Choi D, Chun S, Oh H, Han J, Kwon T. 2020. Rumor Propagation is Amplified by Echo Chambers in Social Media. Sci Rep 10:(310)doi.org/10.1038/s41598-019-57272-3

Cook J, Nuccitelli D, Green SA, Richardson M, Winkler B, Painting R, Way R, Jacobs P, Skuce A. 2013. Quantifying the consensus on anthropogenic global warming in the scientific literature. Environmental Research Letters 8:(2)opscience.iop.org/article/10.1088/17489326/8/2/024024/meta

Cook J, Oreskes N, Doran PT, Anderegg WRL, Verheggen B, Maibach EW, Carlton JS, Lewandowsky S, Skuce AG, Green SA, Nuccitelli D, Jacobs P, Richardson M, Winkler B, Painting R, Rice K. 2016. Consensus on consensus: a synthesis of consensus estimates on human-caused global warming. Environmental Research Letters 11:(4)doi.org/10.1088/17489326/11/4/048002

Cook C, Schaafsma J, Antheunis M. 2018. Under the bridge: An in-depth examination of online trolling in the gaming context. New Media \& Society 20:(9) 33233340doi.org/10.1177/1461444817748578

Dalley S. 2009. Myths from Mesopotamia: Creation, The Flood, Gilgamesh, and Others. Oxford: Oxford University Pressamazon.com/dp/0199538360

Diffenbaugh NS, Burke M. 2019. Global warming has increased global economic inequality.Proceedings of the National Academy of Sciences 116:(20) 98089813doi.org/10.1073/pnas.1816020116

Dijksterhuis A, Spears R, Postmes T, Stapel D, Koomen W, Knippenberg A, Scheepers D. 1998. Seeing one thing and doing another: Contrast effects in automatic behavior. Journal of Personality and Social Psychology 75:(4) 862-871dx.doi.org/10.1037/0022-3514.75.4.862

Dimant E, Tosato G. 2017. Causes and Effects of Corruption: What has Past Decade's Empirical Research Taught us? A Survey. Journal of Economic Surveys 32 doi.org/10.1111/joes.12198

Egeland B, Sroufe A. 1981. Developmental sequelae of maltreatment in infancy. Wiley, New Directions for Child and Adolescent Development 11: 77-92doi.org/10.1002/cd.23219811106

Flegal KM, Kit BK, Orpana H, Graubard BI. 2013. Association of all-cause mortality with overweight and obesity using standard body mass index categories: A systematic review and meta-analysis. Journal of the American Medical Association 309: 71-82 doi.org/10.1001/jama.2012.113905 
Gino F, Pierce L. 2009. The abundance effect: Unethical behavior in the presence of wealth. Organizational Behaviour Human Decision Processes 109:(2) 142155doi.org/10.1016/j.obhdp.2009.03.003

Hawkley LC, Cacioppo JT. 2010. Loneliness matters: a theoretical and empirical review of consequences and mechanisms. Annals of behavioral medicine : a publication of the Society of Behavioral Medicine 40:(2) 218-227 doi.org/10.1007/s12160-010-9210-8

Holt-Lunstad J, Smith TB, Baker M, Harris T, Stephenson D. 2015. Loneliness and Social Isolation as Risk Factors for Mortality: A Meta-Analytic Review. Sage, Perspectives on Psychological Science 10:(2) 227-237doi.org/10.1177/1745691614568352

Holt-Lunstad J, Smith TB, Layton JB. 2010. Social relationships and mortality risk: A meta-analytic review. PLoS Medicine 7:(7) e1000316doi.org/10.1371/journal.pmed.1000316

Howe JP. 2015. This Is Nature; This Is Un-Nature: Reading the Keeling Curve. Environmental History 20:(2) 286-293doi.org/10.1093/envhis/emv005

Jefferson JW. 2001. Social Anxiety Disorder: More Than Just a Little Shyness. Primary care companion to the Journal of clinical psychiatry 3:(1) 4-9doi.org/10.4088/pcc.v03n0102

Kanter JW, Busch AM, Weeks CE, Landes SJ. 2008. The nature of clinical depression: symptoms, syndromes, and behavior analysis. The Behavior analyst 31:(1) 1-21 doi.org/10.1007/bf03392158

Kiss Á. 2009. Divisive politics and accountability. In Essays in Political Economy and International Public Finance (65-78). Frankfurt am Main: Peter Lang AG. Retrieved April 28, 2020jstor.org/stable/j.ctv9hj9t8.5

Koneswaran G, Nierenberg D. 2008. Global farm animal production and global warming: impacting and mitigating climate change. Environmental health perspectives 116:(5) 578582doi.org/10.1289/ehp.11034

Kouchaki M, Smith-Crowe K, Brief AP, Sousa C. 2013. Seeing green: Mere exposure to money triggers a business decision frame and unethical outcomes. Organizational Behaviour Human Decision Processes 121:(1) 53-61doi.org/10.1016/j.obhdp.2012.12.002

Macdonald C. 2019. Money, a disconnecting agent: Reminders of money trigger a feeling of disconnection which increases the likelihood of unethical decisions. The Open Science Journal, 4:(1) 1-10doi.org/10.23954/osj.v4i1.2200

Macdonald C. 2020a. Lexicon connection priming and ethics: As our sense of human connection decreases, so too does our ethical decision-making. The Open Science Journal, 5:(1) 17doi.org/10.23954/osj.v5i1.2276

Macdonald C. 2020b. Graphical connection priming and ethics: As our sense of human connection decreases, so too does our ethical decision-making. The Open Science Journal, 5:(1) 16doi.org/10.23954/osj.v5i1.2275

McMillan FD. 2016. The psychobiology of social pain: Evidence for a neurocognitive overlap with physical pain and welfare implications for social animals with special attention to the domestic $\operatorname{dog}$ (Canis familiaris). Elsevier, Physiology \& Behavior 167:(1) 154171doi.org/10.1016/j.physbeh.2016.09.013

Mittal I, Gupta RK. 2015. Natural Resources Depletion and Economic Growth in Present Era. SOCHMastnath Journal of Science \& Technology 10:(3)ssrn.com/abstract=2920080

Pelletier KL. 2010. Leader toxicity: An empirical investigation of toxic behavior and rhetoric. Leadership 6:(4) 373-389doi.org/10.1177/1742715010379308

Price-Thomas G, Turnbull N. 2018. Thickening Rhetorical Political Analysis with a Theory of Distance: Negotiating the Greek Episode of the Eurozone Crisis. Political Studies 66:(1) 209-225 doi.org/10.1177/0032321717708764

Schmidt M. 2019. Gilgamesh: The Life of a Poem. Princeton: Princeton University Pressamazon.com/dp/B07RPCHCWF

Sandars NK. 1972. The Epic of Gilgamesh. London: Penguin Classicsamazon.com/dp/B00GLSFUUK

Scarborough P, Appleby PN, Mizdrak A, Briggs ADM, Travis RC, Bradbury KE, Key TJ. 2014. Dietary greenhouse gas emissions of meat-eaters, fish-eaters, vegetarians and vegans in the UK. Climatic Change 125: 179-192doi.org/10.1007/s10584-014-1169-1

Törnberg P. 2018. Echo chambers and viral misinformation: Modeling fake news as complex contagion. PLoS ONE 13:(9) e0203958doi.org/10.1371/journal.pone.0203958

Vieira S. 2012. Inequality on the rise? An assessment of current available data on income inequality, at global, international and national levels. DESAun.org/en/development/desa/policy/wess/wess_bg_papers/bp_wess2013_svieira1.pdf

Vohs KD. 2015. Money Priming Can Change People's Thoughts, Feelings, Motivations, and Behaviors: An Update on 10 Years of Experiments. Journal of experimental psychology General 144:(4) e86-e93dx.doi.org/10.1037/xge0000091

Wang J, Wu X, Lai W, Long E, Zhang X, Li W, Zhu Y, Chen C, Zhong X, Liu Z, Wang D, Lin H. 2017. Prevalence of depression and depressive symptoms among outpatients: a systematic review and meta-analysis. BMJ open 7:(8) e017173doi.org/10.1136/bmjopen-2017-017173 
Zyglidopoulos S, Hirsch P, Martin de Holan P, Phillips N. 2017. Expanding Research on Corporate Corruption, Management, and Organizations. Journal of Management Inquiry 26:(3) 247253doi.org/10.1177/1056492617706648 